\title{
Trabalho, história ambiental e cana-de-açúcar em Cuba e no Brasil
}

Labor, Environmental History, and Sugar Cane in Cuba and Brazil ${ }^{1}$

Aviva Chomsky*

Rogers, Thomas

The Deepest Wounds: A Labor and Environmental History of Sugar in Northeast Brazil

Chapel Hill: University of North Carolina Press, 2010. xvi + 302p.

McGillivray, Gillian

Blazing Cane: Sugar Communities, Class, and State Formation in Cuba, 1868-1959

Durham, NC: Duke University Press, 2009. xxiii + 386p.

Wolford, Wendy

This Land Is Ours: Social Mobilization and the Meanings of Land in Brazil

Durham, NC: Duke University Press, 2010. xii +281 .

Funes Monzote, Reinaldo

From Rainforest to Cane Field in Cuba: An Environmental History since 1492

Chapel Hill: University of North Carolina Press, 2008. xv $+357 p$.

Tanto a história do trabalho quanto a do meio ambiente são campos de estudo florescentes e estão, fundamentalmente, relacionadas de muitos modos em termos estruturais. Apesar disso, os historiadores têm sido lentos em aceitar sua relação. A historiografia espelha profundas divisões entre os próprios movimentos trabalhista e ambientalista, talvez porque muitos historiadores cheguem a seus estudos a partir de um envolvimento, ou pelo menos de uma simpatia, com esses movimentos. Os quatro livros aqui resenhados, ao mesmo tempo em que são - cada um por sua própria conta - interessantes e significativos, mostram, coletivamente, o estado ainda nascente da capacidade dos historiadores em conceituar e investigar as formas pelas quais o trabalho e o meio ambiente estão conectados.

* Salem State University. achomsky@salemstate.edu 
O aparente conflito "empregos versus meio ambiente" tem afligido os movimentos trabalhista e ambientalista nos Estados Unidos há décadas e é frequentemente propagado pela indústria, que nitidamente é o vencedor em uma batalha na qual o trabalhismo se vê compelido a unir forças ao capital para se defender dos desafios ambientais. No entanto, o trabalhismo também tem sido fundamentalmente enfraquecido por esse posicionamento, pois a indústria volta o mesmo argumento contra os trabalhadores, transformando-o em "empregos versus salários, benefícios e condições de trabalho", e às vezes até mesmo "empregos versus sindicatos". Enquanto isso, os ambientalistas parecem ter poucas respostas para a acusação de que se importam mais com a fauna exótica do que com as necessidades humanas.

A América Latina dificilmente tem ficado imune a essas correntes. Apesar disso, um envolvimento mais incisivo com a história, uma relativa imunidade às tendências políticas da Guerra Fria que vincularam os sindicatos americanos a uma estreita agenda focada no crescimento econômico e os inevitáveis confrontos com o imperialismo americano em suas muitas formas ajudaram o trabalhismo latino-americano a manter uma postura mais independente e, às vezes, até mesmo revolucionária. Como Charles Bergquist salientou há várias décadas, quando os trabalhadores são nativos e o capital é estrangeiro, o trabalhismo frequentemente se mobiliza para fazer parte de coalizões revolucionárias nacionalistas. Enquanto isso, os camponeses latino-americanos impulsionaram o que Joan Martínez-Alier e outros chamaram de "ambientalismo dos pobres" em defesa de seus meios de vida. O status colonial e neocolonial da América Latina moldou fundamentalmente sua história do trabalho e do meio ambiente (Bergquist, 1995; Martínez-Alier, 2005).

"O que está acontecendo com as comunidades nos afeta, porque fazemos parte das comunidades", explicou-me o presidente de um sindicato de mineiros de carvão da Colômbia há vários anos. "Como organização sindical com uma visão social ampla, não podemos nos distanciar dos impactos sociais e ambientais da mina.” Ativistas antimineração a céu aberto na Appalachia ficam perplexos ao ouvir um líder sindical expressar essas opiniões. A análise anti-imperialista e marxista nos sindicatos latino-americanos leva muitos a concluir que as empresas estrangeiras estão explorando igualmente o trabalho e o meio ambiente, saqueando os recursos de seu país na busca do lucro.

Entretanto, uma ativista do Sierra Club ficou menos satisfeita com a resposta que recebeu quando perguntou a outro líder do mesmo sindicato: "Você não concorda que temos de deixar o carvão para trás?". "Você está perguntando para a pessoa errada", respondeu ele lentamente. "Nós estamos extraindo 
aquele carvão para vocês. Se vocês querem ir além do carvão, têm que olhar para vocês mesmos." Nesse momento, ele pegou diretamente no calcanhar de Aquiles do movimento ambiental norte-americano. Muitos ambientalistas do Primeiro Mundo querem salvar a Terra sem enfrentar o problema político-econômico básico: que os Estados Unidos usam de 25\% a 50\% dos recursos do planeta, e apelos piedosos para "reduzir, reutilizar, reciclar" não mudarão as políticas econômica, externa e militar que mantêm essa injustiça. Assim, Thomas Rogers cita a reação pessimista de um engenheiro brasileiro à propagação dos carros movidos a etanol: "Agora as rodas dos carros do mundo todo vão girar às custas da fome do Nordeste” (p.210).

Para os analistas mais radicais, tanto os do trabalho quanto os do meio ambiente, a desigualdade econômica global é inerente ao próprio capitalismo. Se o capitalismo está baseado no crescimento econômico contínuo, na obtenção de lucro pela exploração da mão de obra e da natureza, então ele se baseia necessariamente na expansão territorial, na destruição do meio ambiente e no empobrecimento da classe trabalhadora. Se a história do meio ambiente examina a relação dos seres humanos com a natureza, e a história do trabalho examina aqueles que trabalham para outros - em geral, pela transformação da natureza -, então o capitalismo e a Revolução Industrial tiveram um papel fundamental em ambas. A substituição do trabalho humano e animal por fontes de energia derivadas de combustíveis fósseis sinalizou um crescimento drástico da capacidade do capital de explorar tanto a mão de obra quanto os recursos.

Historiadores do Terceiro Mundo e teóricos da dependência vêm sustentando há muito tempo que os recursos e a mão de obra do Terceiro Mundo foram cruciais para o desenvolvimento do capitalismo industrial. Mais recentemente, historiadores como Kenneth Pomeranz e Richard P. Tucker ofereceram uma análise explicitamente ecológica desse processo, examinando como a destruição ambiental foi deslocada para as colônias. De maneira perversa, os colonizadores, que primeiro empurraram os povos nativos para terras frágeis para abrir espaço para seus novos empreendimentos econômicos, acusaram os mesmos nativos de macular a "selva" colonial remanescente com sua presença e suas práticas tradicionais - o ambientalismo tornou-se, assim, um outro estágio do imperialismo. É claro que essas expropriações também tiveram, historicamente, um componente laboral, desde as primeiras medidas de apropriação de terras que acompanharam a Revolução Industrial: elas "libertam" os antigos habitantes para entrarem no mercado de trabalho. ${ }^{2}$ 
Os quatro livros aqui resenhados examinam regiões moldadas pelo colonialismo e, especificamente, pelo açúcar. $\mathrm{O}$ açúcar foi a primeira agroindústria, e aquela na qual, segundo Sidney Mintz, o sistema escravista criou o proletariado original, o modelo para as primeiras fábricas da Grã-Bretanha, bem como uma fonte alimentar primordial para os primeiros trabalhadores industriais da Europa. Como Manuel Moreno Fraginals e outros têm sustentado há muito tempo, as plantações de cana-de-açúcar devoraram vorazmente tanto as pessoas quanto as florestas (Mintz, 1985; Moreno Fraginals, 1976). Todos os livros sugerem questões profundas sobre a natureza global do capitalismo e seus impactos nos seres humanos e no meio ambiente.

Apenas The Deepest Wounds assume a tarefa de realmente conectar as histórias do trabalho e do meio ambiente, focando o Nordeste do Brasil. O livro de Wolford This Land is Ours Now é um estudo de um movimento social brasileiro, intimamente conectado às questões do trabalho e do meio ambiente, que começa, em termos cronológicos, exatamente onde Rogers para. A história ambiental de Cuba de Funes Monzote oferece ideias sugestivas sobre o trabalho, ao passo que Blazing Cane, a história política e do trabalho de McGillivray, levanta questões relevantes para o meio ambiente. Lidos em conjunto, os quatro mostram como o colonialismo e o açúcar estruturaram o debate político em Cuba e no Brasil e oferecem percepções e ideias adicionais sobre como uma história conjunta do trabalho e do meio ambiente pode constituir um empreendimento frutífero.

Funes Monzote assume a visão de mais longo prazo em From Rainforest to Canefield. O título capta com precisão o foco do livro, que consiste, primordialmente, nas florestas de Cuba e nos debates acerca de seu valor e seus usos, com a vitória gradual das plantações de cana-de-açúcar. É, primordialmente, uma história política de questões ambientais, e a história do trabalho está implicada na medida em que as questões trabalhistas nos campos de cana-de-açúcar estão inevitavelmente entrelaçadas com sua expansão e seu esgotamento. É também uma história das ideias, na medida em que os cubanos e seus senhores coloniais se debateram em torno do significado e da finalidade da floresta, e do relacionamento dos seres humanos com a natureza.

Funes Monzote conta a agora conhecida história da expansão das plantações de cana-de-açúcar, primeiro pelo oeste de Cuba, e depois para o leste, destruindo vorazmente florestas em seu caminho. Cuba, sugere ele, "oferece um dos casos mais representativos dos primórdios da agricultura industrial nas Américas”. Diferentemente da agricultura tradicional, que se baseava no princípio de manutenção da viabilidade da terra, a agricultura industrial se 
baseia na transformação de um recurso renovável - a terra - em um recurso não renovável - ela "funcionou como minas a céu aberto" (p.265).

A cana-de-açúcar exigia não apenas terra para plantar, mas também madeira para combustível, e os donos de plantações cubanos simplesmente se mudaram para novas terras quando esgotaram as suas. Funes Monzote vai além de explicações anteriores e examina a história política e cultural que está por trás do processo: o que a floresta significava para diferentes setores da sociedade cubana e colonial, como eles tentaram impor suas visões e como esse debate moldou a sociedade cubana. Ele reconstrói a maneira como diferentes forças sociais e políticas competiram para impor seus interesses por meio da legislação e da ação, tendo todas o desaparecimento gradativo da floresta como objeto. "Além de avaliar a influência da evolução socioeconômica da ilha e das ideologias dominantes nas atitudes para com o meio ambiente, meu objetivo aqui é destacar a importância das florestas na formação da nação cubana ... Esse livro é uma homenagem à importância silenciosa das florestas na história de Cuba" (p.5).

A floresta teve um papel central nos debates sobre o papel do Estado e a distinção entre público e privado, nos crescentes conflitos entre os interesses coloniais espanhóis e um setor "cubano" emergente, nos conceitos de propriedade privada e na noção de bem comum, e no surgimento de ideias sobre a natureza e sua finalidade, ou o relacionamento dos seres humanos com a natureza.

Durante boa parte do período colonial, os principais atores do debate foram a Marinha Real, que queria preservar as florestas para o uso da madeira na construção de navios, e os canavieiros, que reivindicavam soberania sobre as terras que controlavam. Nesse aspecto, o debate em Cuba espelhou - e às vezes prefigurou - o que aconteceu em outros lugares do mundo colonial. ${ }^{3}$ Tanto a Marinha como os canavieiros viam a floresta em termos economicamente instrumentais, mas seus interesses diferentes os levaram a atitudes e políticas diferentes. Para os donos de plantações, as florestas existiam para serem derrubadas, para a obtenção de combustível ou cana. Para a Marinha, o valor da floresta estava em sua madeira, e, para ser economicamente útil, ela precisaria ter condições de se regenerar. "Os burocratas da Marinha viam o comércio de açúcar como a maior ameaça à construção naval na ilha - não apenas em razão da competição pelo uso da madeira abundante, mas também pelo fato de que plantar cana-de-açúcar eliminava a possibilidade de a mata se regenerar. As características da indústria açucareira naquele período, especificamente sua necessidade de madeira, lenha e solo fértil, eram justificativas 
suficientes para esses receios" (p.43). "A indústria da construção naval e a indústria açucareira tinham duas concepções irreconciliáveis sobre como as florestas deveriam ser exploradas. Isso não significa que, para a primeira, a proteção das florestas fosse um fim em si mesmo, mas os construtores navais viam a mata como um recurso que, se explorado de maneira razoavelmente ordenada, poderia se regenerar" (p.59).

A posição da Marinha também a levou a articular um bem comum que suplantava aquele do capital privado. Como sustentou o comandante da Marinha Juan de Araoz no final do século XVIII, "para se alcançar essa conservação, os abusos e a liberdade dos homens devem ser reprimidos ... o indivíduo nunca vai levar nada em conta a não ser seu interesse privado, que precisa ficar mudo quando defrontado com o interesse geral" (p.107). Quase cem anos mais tarde, um engenheiro florestal espanhol refletiu a mesma postura, lamentando "o egoísmo e a avareza dos indivíduos, que às vezes não entendem seu próprio interesse e são indiferentes ao interesse geral” (p.209). E, em 1918, o botânico cubano Juan Tomás Roig alertou que o governo deveria intervir para "cuidar do futuro da agricultura nacional, frente ao fato de que 'os donos de plantações só davam atenção a seu interesse privado e imediato"' (p.239).

Nas ilhas menores do Caribe, os canavieiros aprenderam a fazer o cultivo de formas mais sustentáveis - usando o bagaço da cana como combustível, por exemplo. Mas a natureza aparentemente infindável das florestas de Cuba e sua entrada tardia na produção de açúcar - em Cuba, "a produção de açúcar decolou na aurora da era industrial” - incentivaram os donos de plantações a imaginar uma expansão infinita como o caminho mais lógico e lucrativo (p.265). Em poucas gerações, os recursos acumulados em séculos de crescimento das florestas foram esgotados.

O debate político se centrava na questão de quem tinha jurisdição sobre as árvores nas terras que o governo colonial arrogara a si mesmo como Reservas Florestais Reais, e de quanto controle os donos das terras tinham sobre as terras que eram oficialmente deles. À medida que a indústria açucareira se expandia rapidamente no final do século XVIII e começo do século XIX, o conflito colocou a Marinha na posição de ambientalista, defendendo o uso sustentável da floresta e a primazia do bem público sobre o ganho privado. A discussão envolvia mais do que simplesmente a floresta: "Essa batalha contra os limites estabelecidos para a exploração das florestas cubanas atendendo ao interesse da construção naval tornou-se central para as mudanças que ocorriam na estrutura agrícola da ilha e para o triunfo das concepções dos donos 
de plantações e do liberalismo na esfera econômica da colônia" (p.89). Esse triunfo aconteceu em 1815, quando as Cortes de Cádiz estabeleceram "o direito 'sagrado' de propriedade defendido pela primeira revolução burguesa da Espanha" (p.121). É claro que esse direito de propriedade se estendeu também à mão de obra, "mão de obra escrava como uma fonte de enriquecimento rápido, resultando de uma visão de mundo gananciosa no tocante aos seres humanos e ao meio ambiente" (p.128).

Ao final do século XIX, novas fontes de combustível (bagaço de cana e carvão) começaram a substituir a lenha nos engenhos, mas a necessidade de derrubar florestas não diminuiu, já que a indústria estava se expandindo rapidamente e o solo de plantações antigas se esgotava. A preocupação com o esgotamento da terra contribuiu para o questionamento do próprio sistema escravista e sua relação com o uso ineficiente de recursos (p.153). "Se alguém era livre para comprar e vender escravos negros, por que não seria livre para explorar as florestas?” (p.275). Cientistas espanhóis e membros da Sociedade Econômica de Havana reavivaram discussões sobre a necessidade de subordinar o interesse privado ao bem público e levantaram a questão da sustentabilidade de longo prazo: "o homem não vive apenas pelos poucos dias em que exerce seu papel; a posteridade pode também exigir dele uma severa prestação de contas pelo mal que ele fez ou permitiu que acontecesse àqueles bens que negou a seus descendentes" (p.159).

O final do século XIX assistiu à rápida expansão do açúcar para o leste da ilha, sob o novo sistema do central, o engenho grande e industrializado, que separou o cultivo do processo de moagem. Os novos centrales "ajudaram a acabar com a portabilidade da indústria” - limitando, assim, em termos, a derrubada sem fim da floresta -, mas "a existência de mata abundante na metade leste da ilha permitiu aos canavieiros continuar estabelecendo plantações de cana-de-açúcar em terra virgem, agora com um impacto muito maior por unidade" (p.187).

Enquanto vemos o Estado colonial desenvolvendo uma noção de bem público que o coloca em oposição à classe dos donos de plantações, o autor complementa os argumentos de Kenneth Pomerantz e Richard Tucker sobre a importância ambiental das colônias para o projeto industrial. As florestas de Cuba deveriam ser preservadas para compensar o esgotamento das florestas da própria Espanha, e "grande parte da rica biodiversidade da ilha foi consumida para satisfazer as necessidades alimentares dos nascentes centros industriais da Europa e dos Estados Unidos" (p.66, 275). Os súditos coloniais tinham menos direitos do que os súditos metropolitanos porque a finalidade da 
colônia era servir aos interesses da metrópole. Outro oficial da Marinha sustentou que "a liberdade ... tão atrativa e inocente na Península, não é praticável aqui, porque ela beneficiaria o indivíduo em detrimento da nação inteira e seus interesses" (p.113). Vemos aí também, talvez, uma fantasmagórica prefiguração dos ambientalistas imperiais de hoje, cuja preocupação com a floresta tropical amazônica coexiste despreocupadamente com sua promoção dos biocombustíveis que a estão destruindo.

Funes Monzote chama o começo do século XX, quando o capital norte-americano jorrou no país e as plantações inundaram o leste de Cuba, de "o ataque final à floresta" (capítulo 6). O progresso econômico significou destruição ambiental. "Em nenhum outro momento da história cubana o país experimentou maior crescimento em seu 'potencial produtivo', assim como em nenhum outro momento o desmatamento e a mudança ambiental foram tão intensos" (p.218). Em 1926, o presidente Machado retornou a ideais anteriores ao século XIX quando assinou um decreto proibindo a derrubada de árvores tanto em terras privadas quanto nas públicas. Àquela altura, porém, "infelizmente era tarde" para proteger a floresta do leste de Cuba (p.229).

O livro Blazing Cane, de Gillian McGillivray, oferece uma boa contrapartida ao de Funes Monzote na medida em que enfatiza o século XX; assim, retoma cronologicamente a questão onde Funes Monzote termina e privilegia o aspecto do trabalho da história da cana-de-açúcar em Cuba. Um tema-chave para McGillivray é o relacionamento entre os trabalhadores, os canavieiros e o Estado, bem como a natureza do populismo latino-americano. Em geral, o populismo tem sido estudado como um fenômeno urbano na América Latina. No entanto, ao impor sua própria força à custa da classe dos donos de plantações, mesmo um Estado conservador pode apelar para os interesses de classe dos trabalhadores rurais, de maneira comparável ao modo como o Estado colonial de Funes Monzote e o Estado machadista relegaram os interesses dos canavieiros para proteger a floresta. O estudo de McGillivray foca dois engenhos de açúcar, o Tuinucú, da era colonial, situado na antiga região açucareira central de Cuba, e o Chaparra, da era moderna, estabelecido nas vésperas da independência, em 1895, sendo emblemático dos engenhos grandes, industrializados e majoritariamente de capital estrangeiro que se espalharam pelo leste de Cuba durante esse período: parte do "ataque final à floresta" de Funes Monzote.

Suas questões principais, no entanto, são políticas: como o Estado, os capitalistas e as classes populares negociaram o poder nessa sociedade dominada pela cana-de-açúcar. Ela identifica três períodos: “'o pacto colonial' 
(1780-1902), 'o pacto patronal' (1902-1932) e 'o pacto populista' (1933-1952)” (p.5). No pacto colonial, "os donos de plantações aceitavam o domínio colonial em troca da proteção militar e legal da escravidão e da produção de açúcar por parte da Espanha" (p.14). Sob o pacto patronal, que o substituiu, "os capitalistas estrangeiros e seus intermediários cubanos estabeleceram o controle econômico e político sobre boa parte da população rural da ilha através de uma combinação de repressão, clientelismo, incluindo assistência social privatizada nas plantações, e exploração do fascínio dos 'cubanos' pelo progresso e a modernidade” (p.86). Esse também foi o período em que a cana-de-açúcar se espalhou pelo leste da ilha. Finalmente, sob o pacto populista, o Estado assumiu o papel de mediar os grupos de interesse e proporcionar assistência social.

Diferentemente de outros historiadores que enfatizaram o caráter excepcional de Cuba como uma virtual colônia dos Estados Unidos, McGillivray enfatiza as semelhanças com o resto da América Latina no desenvolvimento econômico, social e político de Cuba. Seu argumento de que o Estado fortalecido depois de 1933 criou, em certo sentido, classes sociais na medida em que estabeleceu canais através dos quais elas podiam manifestar seus interesses, substituindo as relações patrono-cliente que caracterizaram os dois primeiros períodos, está em paralelo ao que Rogers descreve sobre o Brasil.

A indústria açucareira de Cuba estava organizada de maneira um tanto diferente da do Brasil, pois boa parte da cana era produzida por pequenos agricultores ou colonos, que formavam um terceiro setor social na região açucareira, além dos donos de plantações/engenhos e dos trabalhadores. A maioria dos colonos era cubana, ao contrário dos donos dos empreendimentos maiores, e muitos também dependiam de mão de obra contratada ou até mesmo de subcolonos para trabalhar seus campos. Eles estavam vinculados aos engenhos maiores porque era lá que vendiam sua cana, e especialmente no leste, porque eram, muitas vezes, arrendatários do engenho. Além disso, muitos dos trabalhadores nas novas plantações do leste eram migrantes contratados na Jamaica, no Haiti ou em outras ilhas das Índias Ocidentais. Os colonos desempenham um papel-chave na tentativa de McGillivray de revisar a historiografia de Cuba.

A historiografia cubana estabelece, tradicionalmente, uma dicotomia clara entre as plantações mais antigas, menores e de propriedade de cubanos no oeste, com seus trabalhadores nativos e uma relação mais igualitária com os colonos, e as plantações de propriedade de norte-americanos no leste, com seus trabalhadores importados das Índias Ocidentais e seus colonos arrendatários completamente subordinados. McGillivray mostra que a realidade é 
mais complexa. A família Rionda, geralmente vista como representante dos canavieiros nacionais do oeste, era radicada na Espanha, em Cuba e nos Estados Unidos, e o capital do engenho, como até mesmo os escritórios, estavam tanto dentro quanto fora de Cuba. Os donos de engenho tanto do leste quanto do oeste consideravam vários fatores ao optar por produzir cana diretamente ou comprá-la dos colonos. Tanto os colonos arrendatários quanto os independentes se mobilizavam em coalizões nacionalistas e revolucionárias, como também para defender seus interesses particulares. De fato, sustenta ela, os trabalhadores e colonos do leste tinham, em alguns aspectos, mais poder que os do oeste, porque conseguiam mobilizar o sentimento nacionalista em seu favor (p.274).

Os colonos surgem como ator político significativo tanto no leste quanto no oeste de Cuba, em particular, nas revoluções de 1933 e 1959. Em 1933, como o pacto patronal entrou em colapso sob o peso da Depressão, trabalhadores e colonos se voltaram para o Estado, dando origem ao novo pacto populista. Assim como no Brasil sob a ditadura militar, tratava-se de um "populismo autoritário" (Blazing Cane, p.227). Tanto Rogers quanto McGillivray nos oferecem novas perspectivas a respeito de como até mesmo os mais direitistas governos autoritários conseguem, com sucesso, atrair as classes trabalhadoras. Ao criar instituições estatais fortes que intervenham nas relações de trabalho, os populistas conseguem quebrar o jugo das classes dos donos de plantações e criar certas garantias para os trabalhadores. Apesar de inicialmente destruir os sindicatos independentes e reduzir até mesmo os insuficientes benefícios de saúde e educação aos quais os trabalhadores tinham acesso sob o pacto patronal, Fulgencio Batista também implementou um sistema de participação nos lucros e, ao final dos anos 1930, havia se reconciliado com os sindicatos e aprovado uma legislação trabalhista progressista (p.244). A Constituição de 1940 "era talvez a mais progressista da América Latina, pelo menos no papel”, e "estabeleceu o Estado de bem-estar social cubano" (p.248).

Ao enfatizar o caráter populista dos governos de Cuba em meados do século XX, McGillivray restabelece o lugar da ilha nos processos históricos latino-americanos. Ao explicar como "o anticomunismo da Guerra Fria de 1947 a 1959 esvaziou o pacto populista de Cuba e o privou de grande parte de sua substância”, ela também oferece novas percepções sobre a revolução de 1959 (p.228). "A forte reação negativa da Guerra Fria, a partir de 1947, começou a minar o valor social-democrático das instituições populistas ao priorizar novamente clientes individuais em vez de grupos de classe ... A Guerra Fria tirou grande parte do espaço que os grupos populares tinham conquistado 
dentro do populismo de meados do século XX” (p.275). Interessantemente, McGillivray se distancia de explicações segundo as quais o relacionamento com os Estados Unidos determinou excessivamente os acontecimentos em Cuba em períodos anteriores; nessa última década foi a política de Guerra Fria dos Estados Unidos que empurrou o governo Batista do populismo para a repressão e abriu caminho para a Revolução de 1959.

O livro The Deepest Wounds, de Thomas D. Rogers, é o que mais diretamente enfrenta o desafio de escrever uma história do trabalho e do meio ambiente. "A despeito das claras ligações entre o meio ambiente e o trabalho rural ... os pesquisadores ainda precisam construir um marco satisfatório para analisar os dois paralelamente", escreve ele (p.4). Ele poderia estar criticando os dois livros recém-discutidos, já que o trabalho rural está praticamente ausente na história ambiental de Funes Monzote, ao passo que o ambiente natural mal aparece na análise de McGillivray a respeito do trabalho e da política.

Para enfrentar a tarefa, o estudo de Rogers acerca da região açucareira no Brasil propõe os conceitos de paisagem - que incorpora tanto as crenças humanas sobre a terra quanto sua realidade material - e de "agroambiente" na medida em que ele molda a ação humana - e, em particular, o trabalho - e é moldado por ela. Como em Cuba, o sistema de plantações no Brasil se baseou na escravidão até o final do século XIX, e em uma forma de política republicana autoritária durante a maior parte do século XX.

Os donos de plantações e os trabalhadores tinham noções muito diferentes de paisagem. Em relação aos donos de plantações, Rogers analisa como o abolicionista Joaquim Nabuco, o romancista José Lins do Rego e o sociólogo Gilberto Freyre expressaram uma sensibilidade ecológica ao estabelecerem ligações claras entre a degradação da terra e do trabalho através do sistema escravista. Eles vislumbraram uma "paisagem trabalhadora" (p.45) em que o "comando" dos canavieiros tornava a terra e o trabalho produtivos. Apesar de críticos ao sistema, eles injetaram em suas obras uma grande dose de nostalgia, sugerindo que as relações patriarcais mantiveram o sistema em equilíbrio até a introdução da usina ou dos modernos engenhos de açúcar industriais ao final do século XIX: "Tanto os trabalhadores quanto a terra foram degradados pela nova indústria moderna e eficiente" (p.57). A nostalgia deles pela paisagem estava imbuída da nostalgia pelas relações sociais inseridas nela. "O que eles proclamavam como amor telúrico não era paixão pela natureza, mas apreço pela dinâmica da exploração racial, de classe e ambiental que constituía a paisagem trabalhadora da zona açucareira" (p.69). Assim, a análise do Brasil do século XIX feita por Rogers é paralela - e dá uma nuance ambiental - ao que 
McGillivray descreve em Cuba como o "pacto colonial", e explora os aspectos laborais dos debates coloniais que Funes Monzote explora.

Para os trabalhadores, em contraposição a isso, a paisagem, corporificada nas lavouras de cana-de-açúcar, significava cativeiro. A abolição da escravatura não mudou a dinâmica fundamental de poder, já que os donos de plantações continuaram a controlar a terra. Os antigos escravos tornaram-se arrendatários: "o sistema manteve os trabalhadores presos aos engenhos mesmo sem o vínculo jurídico da escravidão" (p.73). Não houve uma fuga em massa das plantações, não houve um restabelecimento do campesinato, mas havia, de fato, um desejo por terra. "Visto que os donos de plantações tinham um quase monopólio da propriedade fundiária, o único acesso 'legítimo' dos trabalhadores à terra era mediante algum tipo de arrendamento; o caminho para o acesso passava pela provisão de mão de obra" (p.92). Quando os trabalhadores fugiam efetivamente das plantações, o único lugar para o qual eles podiam ir era a cidade. Segundo a exposição de Rogers, pelo menos durante os anos 1940, a cana-de-açúcar significava cativeiro, e os trabalhadores do setor açucareiro do Brasil, tanto quanto os ex-escravos em outros lugares, ansiavam por atingir a verdadeira independência por meio do acesso à terra. Apesar de eles não terem elaborado uma crítica ambiental à cana, o fato de restabelecerem a subsistência contestava implicitamente a destruição ambiental causada pela expansão da agroindústria.

Foi só em meados do século XX que a intervenção da agronomia e do governo trouxe uma expansão, modernização e racionalização da indústria que impôs aos trabalhadores um status mais classicamente proletário, em que seu acesso a lotes na plantação para fins de subsistência se evaporou, especialmente na parte meridional da zona açucareira. Em 1961, mais da metade dos trabalhadores do setor ainda tinha acesso à terra; em 1968, apenas 46\% tinha, e muitos desses tinham um acesso apenas nominal. O desejo pela terra continuou a estimular levantes sociais e trabalhistas nos anos 1960. "Os trabalhadores rurais não tinham uma cultura da preguiça, nem se resignaram coletivamente à miséria ... em meio a circunstâncias mutantes, eles desenvolveram estratégias de trabalho que mais perto chegariam da liberdade em relação ao cativeiro do patrão" (p.124).

A efervescência dos anos 1950 e 1960 atraiu a atenção do Partido Comunista do Brasil e do governo dos Estados Unidos, e ambos acreditavam que a zona açucareira estava madura para a revolução. Agricultores arrendatários das periferias formaram Ligas Camponesas, enquanto o governo brasileiro voltou sua atenção ao "desenvolvimento" do Nordeste. Tanto a Igreja 
Católica quanto os comunistas se lançaram à organização de sindicatos, especialmente após a eleição de um presidente progressista em 1961 e a aprovação de um Estatuto do Trabalhador Rural em 1963. Na parte meridional da zona açucareira, onde a modernização da agricultura e a proletarização estavam mais avançadas, prevaleciam os comunistas; no norte, mais tradicional, era a Igreja. Assim, "fatores ambientais e agrícolas" moldaram o caminho da sindicalização e os atores políticos nela envolvidos (p.140). Em ambas as regiões, porém, a demanda por terra e reforma agrária era central para a organização dos trabalhadores.

O golpe militar de 1964, de acordo com Rogers, "não foi uma vitória inequívoca dos donos de plantações": “em termos da trajetória das lutas dos trabalhadores, houve uma continuidade que transpôs a linha divisória” (p.159). O impacto crucial, no Nordeste, foi a incursão do Estado nas relações entre donos de plantações e trabalhadores, o que inevitavelmente limitou a autonomia dos canavieiros e criou estruturas para os trabalhadores fazerem valer suas demandas. "A simples presença de uma autoridade concorrente no âmbito dos donos de plantações foi a mais importante mudança” (p.162) - algo semelhante ao pacto populista que McGillivray descreve para a Cuba dos anos 1930.

Os canavieiros reagiram com a implementação de um novo regime de trabalho - um regime de subcontratação ou trabalho temporário - para tirar seus trabalhadores do alcance do regime trabalhista do governo. Essa medida rompeu os antigos vínculos, inclusive o arrendamento, que prendiam os trabalhadores às plantações. Nos anos 1970, a maioria dos trabalhadores do setor açucareiro trabalhava sob esses novos esquemas e morava fora das plantações, em pequenas cidades (p.168). Rogers documenta uma crescente divisão entre os líderes sindicais, que continuavam a enfatizar a reforma agrária, e os trabalhadores, que passaram a ver os benefícios do Estado para os trabalhadores como um objetivo mais central, no final dos anos 1960 e início dos 1970. “A terra não era mais a condição sine qua non da liberdade. A mobilidade se tornou importante, com pagamentos feitos de forma confiável, e agora as condições do cativeiro eram entendidas na dicotomia entre o engenho e a rua ... À medida que a liberdade passou a ser associada ao recurso à burocracia do Estado, os trabalhadores se viam com menos frequência em termos 'camponeses', mesmo no tocante à aspiração a ter vínculos com a terra. Eles eram, em primeiro lugar e antes de tudo, assalariados; poder-se-ia dizer que foram proletarizados" (p.178). Comparando-os aos trabalhadores da região de plantação de banana no Equador, e refletindo McGillivray, Rogers cita Steve Striffler para 
sustentar que eles "foram transformados em uma classe por meio do diálogo com o Estado. Foram 'organizados pelo Estado e para dentro dele”" (p.207).

A cana-de-açúcar também foi transformada, em parte, pelo compromisso do governo com a exportação de produtos agrícolas, e, depois do choque do petróleo de 1973, pela produção de açúcar para etanol, utilizando técnicas da Revolução Verde e incentivos econômicos. Novos fertilizantes permitiram que a cana se expandisse para "áreas anteriormente inapropriadas" (p.183). "O preço pago pela expansão da cana-de-açúcar foram córregos fétidos, céus repletos de cinzas, florestas derrubadas e maior número de enchentes” (p.201).

Foi uma solução típica de direita para as gritantes desigualdades latino-americanas: expandir sem redistribuir. No entanto, como nos lembra Rogers, "um dos problemas dos projetos de crescimento econômico altamente modernizantes foi que eles deixaram de levar em consideração o meio ambiente" (p.184). Especialmente no norte da zona açucareira, que havia sido menos afetado pelas modernizações anteriores, os efeitos ambientais foram drásticos. Essas mudanças, combinadas à abertura política do final dos anos 1970, levaram a um renascimento da sindicalização e das greves entre os trabalhadores do setor canavieiro. A gravidade da degradação ambiental no norte ajuda a explicar por que ele foi o epicentro das atividades sindicais e grevistas, em contraposição aos anos 1960 (p.196).

O trabalho e o meio ambiente estão conectados na medida em que o lucro, ou o desenvolvimento econômico, depende do controle de ambos - embora o capital não possa, verdadeiramente, controlar nenhum dos dois. "Assim como os donos de plantações antes dela, a ditadura pensou que comandava a paisagem. Em ambos os casos, esse controle era uma ilusão. Essas falhas equivalem a uma denúncia da própria noção de comando como abordagem à gestão do meio ambiente ou da mão de obra" (p.204).

Apesar de Rogers nos oferecer uma história na qual os trabalhadores do setor açucareiro buscaram, por séculos, escapar da cana e ganhar acesso à terra para fins de agricultura de subsistência, ele também sugere que a paisagem pode ajudar a explicar o compromisso dos trabalhadores com a cana-de-açúcar hoje. "A visão das pessoas a respeito de sua localização - das possibilidades e realidades de sua vida - é estruturada por discursos sobre a paisagem. Esse conceito nos permite pensar sobre os impactos materiais desses discursos, entrelaçando fios culturais com o meio ambiente em si ... Examinar esses discursos melhora nosso entendimento das motivações e perspectivas que orientam as ações das pessoas, e ajuda a explicar por que as raízes da cana-de-açúcar na Zona da Mata são tão profundas. Profundas o suficiente para que nem os 
donos de plantações nem os trabalhadores possam pensar em suas vidas sem ela" (p.217).

O livro This Land is Ours Now, de Wendy Wolford, começa no ponto em que Rogers termina cronologicamente. Um dos mais dinâmicos e conhecidos movimentos rurais que surgiram na América Latina nas últimas décadas é o Movimento dos Trabalhadores Rurais sem Terra (MST), no Brasil. Wolford examina como o MST, nascido entre pequenos produtores no Sul do Brasil, evoluiu e se adaptou ao contexto muito diferente do Nordeste do país, onde, como Rogers mostrou, os trabalhadores do setor açucareiro perderam a maior parte de seus laços com a terra. O livro de Wolford trata de um movimento social, mas a plantação de cana-de-açúcar e a sociedade que ela criou formam um contexto importante: séculos de produção de cana moldaram tanto a história do uso da terra quanto as crenças sobre a terra e a consciência dos trabalhadores. Assim como as outras obras aqui resenhadas sugerem, tanto a história do trabalho quanto a do meio ambiente são, de certa maneira, histórias da consciência: das formas como as pessoas pensam sobre o trabalho e o meio ambiente.

A economia moral, a ideologia e os objetivos do MST, sustenta Wolford, que também se tornaram sua face pública e internacional icônica, refletiam as realidades de pequenos agricultores, em sua maioria descendentes de europeus, do Sul do Brasil. O MST dava ênfase à reforma agrária por meio da invasão de terras e ao desenvolvimento de ideologias e instituições alternativas e socialistas através desse processo. Foi complicado para os trabalhadores do setor açucareiro desempregados do Nordeste, descendentes de escravos africanos, que eram uma força de trabalho totalmente proletarizada buscando trabalho, em vez de terra, ajustar-se a essa abordagem. "Sua decisão de aderir ao MST não era indicativa de um desejo de continuar um modo de vida agrícola ... A crise contínua pela qual passava a indústria da cana-de-açúcar abriu caminho para a aceitação do MST porque havia poucas alternativas no contexto econômico desanimador dos anos 1990 no Brasil ... Nem todo o mundo ficou contente em ter terras próprias, porque eles preferiam ganhar a vida com base no trabalho assalariado e não na agricultura de subsistência" (p.18-19).

Em uma clara inversão de Marx (embora em concordância com os argumentos das obras Peasant Wars of the Twentieth Century, de Eric Wolf, e The Moral Economy of the Peasant, de James Scott), o MST via os trabalhadores do setor açucareiro como "individualistas", em oposição aos valores mais coletivos dos camponeses do Sul (p.19). "Os camponeses são - e sempre foram - os verdadeiros subalternos do Capital, o 'outro’ que legitimou e possibilitou a 
industrialização, a colonização e o desenvolvimento no pós-guerra”, sustenta Wolford (p.70). De certa maneira, a "consciência camponesa" levava a valores coletivos, e os camponeses do Sul estavam, "inicialmente, bastante receptivos à ideia de produção cooperativa ... a forma de produção combinava com seu senso tradicional de comunidade igualitária” (p.104-105). No entanto, os líderes do MST frequentemente constatavam que também os camponeses do Sul eram “individualistas e não conseguiam substituir adequadamente o 'eu' da sociedade capitalista convencional pelo 'nós' da comunidade alternativa do MST" (p.104). Wolford sustenta, porém, que os desafios para os coletivos do MST no Sul do Brasil vinham menos da ideologia camponesa deficiente e mais de dificuldades organizacionais e pessoais dentro dos coletivos do movimento.

Wolford, porém, concorda com Rogers no sentido de que o que ela chama de "hegemonia do discurso açucareiro" prevalece na região açucareira do Nordeste. "Mesmo quando os trabalhadores rurais plantavam frutas e verduras, eles ainda afirmavam que a cana-de-açúcar era a única cultura verdadeiramente viável" (p.185). Como explicou o presidente de um assentamento do MST, muitas vezes os assentados nem se preocupavam em plantar em suas terras recém-obtidas: "Eles estão cansados, têm que sair de casa cedo para cortar cana para terem algo que comer" (p.184). O compromisso ideológico e prático com a cana e com o trabalho assalariado significava que o programa do MST, tão atrativo no Sul, era menos promissor no Nordeste.

Wolford prefacia seu estudo perguntando se é legítimo que uma pesquisadora investigue os problemas e falhas de uma organização que ela admira e que parece oferecer um dos poucos raios de esperança para a crescente população de grupos rurais espoliados no mundo todo. Seu estudo é claramente simpatizante, e ela sustenta que um melhor entendimento dos desafios que se colocam a esse movimento deveria ajudar a fortalecê-lo, e não a enfraquecê-lo. De fato, o compromisso, a visão e a força do MST, e seu potencial para a verdadeira transformação rural, transparecem nessa avaliação sóbria. Uma das conclusões mais desalentadoras dessa obra é que "é muito mais difícil promover o desenvolvimento sustentável do que expropriar terras” (p.128). O MST tem sido mais bem-sucedido em mobilizar e apoiar pessoas nos dias urgentes e empolgantes das ocupações de terra. Mas o desenvolvimento rural sustentável, especialmente em terras esgotadas e no contexto de um capitalismo global neoliberal e declinante, tem permanecido um desafio elusivo virtualmente em toda parte. 
Todos os quatro livros têm como foco regiões moldadas por colonialismo, cana-de-açúcar e escravidão. Todos eles mostram como a própria natureza e as ideias e crenças das pessoas sobre o mundo natural contribuíram para outros desdobramentos políticos e sociais e se cruzaram com eles. No entanto, os quatro livros levam suas análises para direções bem diferentes. Ao comparar duas regiões, Wolford e McGillivray buscam tornar mais complexas as narrativas nacionais - mas de maneiras bem diferentes. Wolford enfatiza as diferenças no contexto do trabalho e do meio ambiente no Nordeste em comparação com o Sul do Brasil e, assim, as experiências muito diferentes que os trabalhadores e camponeses tiveram com o MST nas duas regiões. McGillivray contesta a narrativa nacional bifurcada em Cuba, que propõe padrões muito diferentes para as partes oriental e ocidental da ilha. Ela mostra que, em vez disso, ambas as regiões eram mais como colchas de retalhos.

Adotando uma abordagem explicitamente ambiental de uma longa extensão da história, Funes Monzote e Rogers se ocupam mais diretamente das questões teóricas de como as interações humanas com a natureza contêm um componente crucial da história humana. Em todas as quatro obras, no entanto, a relação entre as pessoas e o meio ambiente tem um papel importante nas histórias política e do trabalho. Cada livro contribui com novas formas de entender o impacto profundo que a cana-de-açúcar teve nas relações sociais, nos movimentos políticos e nos Estados. $\mathrm{O}$ ambiente natural abriu o caminho para a cana-de-açúcar, sofreu a destruição em função dos interesses do açúcar, influenciou a consciência dos trabalhadores, do capital e do Estado nas regiões açucareiras, e continua sendo um fator importante nas lutas do século XXI nessas regiões.

Das quatro obras aqui resenhadas, no entanto, apenas Rogers tenta explicitamente construir uma abordagem teórica que interligue as questões do trabalho e do meio ambiente. Não ficamos sabendo se os formuladores de políticas públicas ambientais de Funes Monzote em Cuba cogitavam a existência de paralelos ou conexões entre a exploração da mão de obra e do ambiente natural, ou como os trabalhadores escravizados ou livres do setor açucareiro cubano concebiam sua relação com o meio ambiente. Além disso, apesar de o açúcar ter sido e continuar sendo um produto colonial e de exportação por excelência, tanto em sua história do trabalho quanto na do meio ambiente ainda há muito a ser explorado com relação à interação de forças globais com essas histórias locais e à natureza dos ambientalismos popular e de elite no mundo pós-colonial. 
A necessidade de histórias que possam nos ajudar a entender as múltiplas ligações entre o trabalho e o meio ambiente é mais urgente do que nunca. Os socialistas latino-americanos do século XXI continuam a se basear em empreendimentos agroindustriais e extrativos para sustentar seus projetos redistributivos e acusam os críticos estrangeiros de imperialismo ambiental. Os movimentos trabalhista e ecológico do Primeiro Mundo se esforçam para ultrapassar análises individuais e localizadas dos problemas que enfrentam. Enquanto isso, a cultura centrada no consumo continua causando estrago até os mais remotos cantos do planeta, ao mesmo tempo em que movimentos pela soberania alimentar ganham impulso. $O$ contexto global, e particularmente $o$ colonial e pós-colonial, continua a estruturar a terra e o trabalho, bem como a compreensão dos sujeitos coloniais a respeito de seu relacionamento com a terra e o trabalho.

Os livros aqui resenhados dão uma importante contribuição para expandir nossas definições e compreensões tanto da história do trabalho quanto da do meio ambiente. A próxima geração da pesquisa vai se basear neles e nas percepções de ativistas latino-americanos das áreas do trabalho e do meio ambiente sobre os contextos e histórias globais que forjaram os sistemas, a consciência e os movimentos trabalhistas e ambientais, bem como as maneiras como esses movimentos, por sua vez, enfrentam os contextos globais. As crises e contradições atuais frisam a importância de se entender como chegamos a esta situação e quais caminhos tomados e não tomados no passado poderiam sugerir futuros alternativos.

\section{REFERÊNCIAS}

BERGQUIST, Charles. Labor in Latin America: Comparative Essays on Chile, Argentina, Venezuela and Colombia. Redwood City, CA: Stanford University Press, 1995. DOWIE, Mark. Conservation Refugees: The Hundred Year Conflict between Global Conservation and Native Peoples. Cambridge, MA: MIT Press, 2009.

GROVE, Richard H. Colonial Conservation, Ecological Hegemony and Popular Resistance: Towards a Global Synthesis. In: MacKENZIE, John M. (Ed.) Imperialism and the Natural World. Manchester: Manchester University Press, 1990.

MARTÍNEZ-ALIER, Joan. The Environmentalism of the Poor: A Study of Ecological Conflicts and Valuation. Oxford: Oxford University Press, 2005.

MINTZ, Sidney Wilfred. Sweetness and Power: The Place of Sugar in Modern History. New York, NY: Viking Press, 1985. 
MORENO FRAGINALS, Manuel. The Sugarmill: The Socioeconomic Complex of Sugar in Cuba, 1760-1860. New York, NY: Monthly Review Press, 1976.

POMERANZ, Kenneth. The Great Divergence: China, Europe, and the Making of the Modern World Economy. Princeton, NJ: Princeton University Press, 2000.

TUCKER, Richard P. Insatiable Appetite: The United States and the Ecological Degradation of the Tropical World. Oakland, CA: University of California Press, 2000.

\section{NOTAS}

${ }^{1}$ Resenha publicada originalmente em Social History, v.38, n.4, November 2013.

2 Pomeranz, 2000; Tucker, 2000; Dowie, 2009; Grove, 1990, p.23, 25. Grove observa que "os primeiros ensaios políticos de Marx e o estimulante, por ele mesmo admitido, de suas primeiras tentativas de análise séria do processo social originam-se de sua preocupação com a criminalização dos camponeses pelas novas leis florestais nos anos 1840" (p.32).

${ }^{3}$ Grove também sustenta que as políticas florestais que protegiam as necessidades de madeira de Marinhas Reais moldaram o pensamento colonial primitivo sobre o meio ambiente e frequentemente colocavam o Estado colonial em conflito com empresas privadas (1990, p.21). Em Cuba, a principal contestação do conservacionismo da Marinha vinha da indústria do açúcar, diferentemente de outros lugares no mundo colonial onde camponeses nativos e povos da floresta foram deslocados por governos coloniais que visavam preservar os recursos para suas próprias finalidades.

Resenha recebida em 23 de fevereiro de 2015. Aprovada em $1^{\circ}$ de março de 2015. 